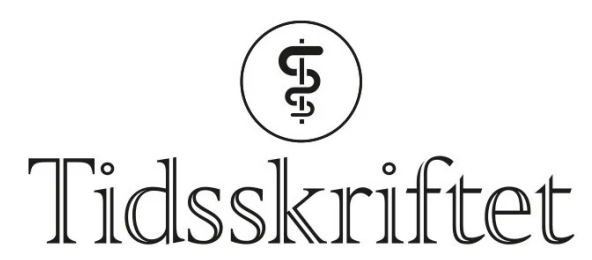

DEN NORSKE LEGEFORENING

\title{
Studentens lyckliga da'r
}

LEGELIVET

\section{KARL O. NAKKEN}

karln@ous-hf.no

Karl O. Nakken er dr.med., nevrolog og pensjonert overlege. Han var i mange år medisinsk ansvarlig ved Spesialsykehuset for epilepsi i Sandvika.

\section{Doktorklubben er tuftet på vår felles studietid i Oslo for rundt 50 år siden. Selv om vi hadde mye moro i de årene, var vi alle lettet da siste eksamen var unnagjort. I ettertid ser vi at dette bare var starten på et livslangt studium der vi aldri blir utlærte.}

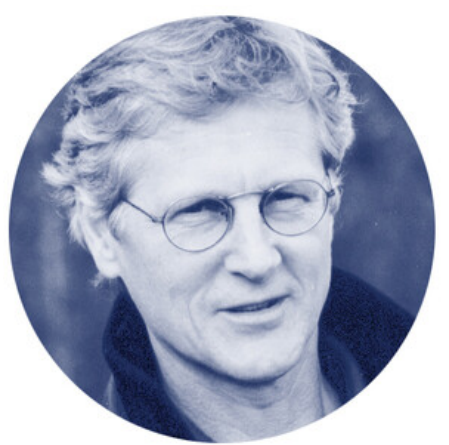

Foto: privat

I studietiden var økonomien skral for de fleste av oss. Noen var riktignok så heldige å ha rundhåndede foreldre. Jeg kan huske en som skrev følgende til foreldrene hjemme: «Til mine biologiske opphav. Jeg tør minne dere om at det er på frukten treet skal kjennes. Dersom frukten deres (jeg) skal bli best mulig, er flere studiepenger en absolutt nødvendighet.» Ved en annen anledning skrev han bare: «Kjære mor og far. Det er dyrt å studere i Oslo. Jeg er blant dem som studerer aller mest. Send mere penger.»

Vi andre måtte støtte oss på Lånekassa. I ukene etter utbetalingen levde noen av oss som grever. Vi kunne spise treretters middag på Theatercafeen eller Blom - gjerne etterfulgt av en bananasplit på Studenten, en isbar på Karl Johan. Med en slik disponering av midlene ble det naturligvis smalhans mot slutten av semestrene. Selv om mange da hadde lite å rutte med, var det likevel en grov overdrivelse når enkelte hevdet å ha det omtrent som hovedpersonen i Hamsun-romanen Sult. 
Vi med hang til tradisjonell norsk mat spiste ofte på Kaffistova. Her klarte en av oss å sjarmere en dame bak disken slik at han alltid fikk gratis påfyll. Til stor misunnelse fra oss andre. Det er nok riktig, det, at kjeften og motet har hjulpet så mange.

På torsdagene spiste vi på søsterhjemmet på Ullevål. Da var det kjøttkaker med kålstuing og polentapudding til dessert. Der var det selvbetjening. Det gikk en historie om en trønder på kullet over oss som hadde satt til livs 21 kjøttkaker. Men rekorden kom med en kostnad. Han var borte fra studiet i flere dager, angivelig på grunn av medistersjokk.

Minner fra selve studiet er blitt bleke med årene. Noen av våre lærere husker vi for deres inspirerende og humørfylte forelesninger. Andre var gørr kjedelige; de var tørrere enn et menighetsblad og like festlige som en stikkpille. En av oss kunne ikke huske annet fra preklinikken enn at Otto Walaas påsto at Krebs-syklusen var rund, og at Jørgen Fogh hevdet hårdnakket at blodet var rødt. Alle husket vi Johan Torgersen som under en forelesning om epididymis oppfordret dem som selv ikke hadde dette organet, å se hos sidemannen.

\section{«Professor, det harjeg kunnet, men dessverre har jeg lcert det bort»}

Muntlig eksamen kunne være et mareritt. At medstudentene hadde anledning til å høre på, gjorde ikke akkurat saken bedre. Vi husket alle en stakkar som ble eksaminert på strukturer som utgikk fra skallebasis. Vi ante at han umulig kunne bestå da han sterkt presset av eksaminator foreslo at spiserøret kom ut gjennom foramen magnum.

Noen håndterte grove kunnskapshull bedre enn andre. En medstudent som åpenbart ikke kunne besvare spørsmålet han fikk, sa da at «professor, det har jeg kunnet, men dessverre har jeg lært det bort».

På den tiden var det vanlig å pynte seg til eksamen. Guttene kom i slips. Jeg har hørt at det nå er slutt på slipsbruken etter at en nervøs og fomlete student skulle rektaleksplorere en pasient til eksamen, og at slipset ble med inn.

\section{«De fant aldri den hårfine balansen mellom å drikke seg til mot og å} drikke seg til idiot»

I studietiden var den seksuelle appetitten stor. Noen hadde en utpreget hormonstyrt atferd. Når dette ble kombinert med alkoholdoseringsvansker, kan de personene i ettertid prise seg lykkelig for at dette var lenge før me too. De fant aldri den hårfine balansen mellom å drikke seg til mot og å drikke seg til idiot. Vi husket godt en medstudent som var litt tafatt når det gjaldt damer. Han hadde lenge vært interessert i ei flott jente som vi andre mente befant seg i en helt annen liga enn ham. Like fullt insisterte han på å gjøre et fremstøt. Og vi tenkte at blind hane kan jo også få seg høne. Som ventet ble fremstøtet en fiasko. Han hadde skjenket seg altfor drøyt på forhånd. Det ble hjem uten klem, med knust hjerte og knuste briller.

På forrige møte i doktorklubben fortalte et medlem at han nylig var kommet til den sørgelige erkjennelsen at tiden vi har her på kloden er begrenset, noe han hadde vansker med å forsone seg med. Han ble sittende å forbanne alderdommen med alle dens fortredeligheter. Han mintes med glede den tiden han var en fyrrig bukk, et vellystig råskinn, en vrinskende bestiger dryppende av stramtluktende sekreter. Men akk, det var lenge siden. Med vemod og resignasjon måtte han slå fast at viriliteten hadde avtatt med 
årene. Ifølge hans erfaring kunne samleiefrekvensen i de forskjellige livsfaser samles under forkortelsen MMA: 20-40 år: Morgen, Middag, Aften. 40-6o år: Mars, Mai, August. Etter 6o år: Muligens Midtsommer Aften.

Publisert: 3. januar 2022. Tidsskr Nor Legeforen. DOI: 10.4045/tidsskr.21.0777

(C) Tidsskrift for Den norske legeforening 2023. Lastet ned fra tidsskriftet.no 26. april 2023. 